\title{
Provincial Foreign Direct Investment Absorptive Capacity of Vietnam
}

\author{
Duong Hoang $\mathrm{Vu}$, Tri Thanh Ho
}

\begin{abstract}
A B S T R A C T
Objective: The objective of the article is to examine the importance of absorptive capacity in the relationship between foreign direct investment and economic performance in 63 Vietnamese provinces from 2007 to 2015.

Research Design \& Methods: The absorptive capacity at provincial level includes six components tested by confirmatory factor analysis, which allows for the argument that absorptive capacity of domestic firms is an important component of absorptive capacity of provinces. Besides this one, there are five other components, including financial development, human capital, the level of openness, the absorptive capacity of domestic firms, institutions, and infrastructure. The generalized two-stages least squares (G2SLS) random effect with instrumental variables regression is used with panel data.
\end{abstract}

Findings: Firstly, foreign direct investment has a positive impact on the development of the 63 provinces in Vietnam. Secondly, among the six components, the four most important ones are infrastructure, the level of openness, human capital, and the absorptive capacity of domestic firms. Moreover, the article finds that foreign direct investment can bring negative impacts to provinces with a low level of trade openness.

Implications \& Recommendations: The government should focus on infrastructure, trading policy, human capital and capability of domestic firms.

Contribution \& Value Added: There is a lack of connection between absorptive capacity at the firm level and the macro level. Therefore, this article attempts to create this connection by constructing absorptive capacity at the firm level as a component of absorptive capacity at the provincial level.

$\begin{array}{ll}\text { Article type: } & \text { research article } \\ \text { Keywords: } & \begin{array}{l}\text { absorptive capacity; openness; financial development; the absorptive } \\ \text { capacity of domestic firms }\end{array}\end{array}$

JEL codes: F14, F23, F62

\section{Suggested citation:}

D.H., Vu, T.T., Ho (2020). Provincial Foreign Direct Investment Absorptive Capacity of Vietnam. Entrepreneurial Business and Economics Review, 8(2), 7-26. https://doi.org/10.15678/EBER.2020.080201 


\section{INTRODUCTION}

Foreign direct investment (FDI) can bring several benefits to the development of host countries. They can be direct benefits, including capital raising, labour creation, trading improvement, or national budget contribution. They can also be indirect effects such as technical transfer or labour turnover. However, FDI can hamper and totally dominate economies by taking advantage of their superior technology and management. Therefore, it seems that if a host nation cannot absorb the benefits from FDI and turn them into domestic strength, sooner or later the market can be dominated by foreign counterparts. It is the reason why this article emphasizes the importance of FDI absorptive capacity. Reflection on absorptive capacity was initiated by Cohen and Levinthal (1989; 1994; 1990). The authors examine the absorptive capacity at the firm level and define it as, "the ability of firms to recognize the value of new, external information, assimilate it, and apply it to commercial ends" (Cohen \& Levinthal, 1990, p. 1). After the root concept of Cohen and Levinthal, various researchers examined this field and studied the role of absorptive capacity. Some focused only on the absorptive capacity at the organizational level (Lane, Koka, \& Pathak, 2006; Lane \& Lubatkin, 1998; Szulanski, 1996; Zahra \& George, 2002), while others looked at the macro level of absorptive capacity (Fu, 2008; Lai, Peng, \& Bao, 2006; Schillaci, Romano, \& Nicotra, 2013). However, according to our knowledge, there is a lack of connection between absorptive capacity at the firm level and the macro level. Therefore, this article attempts to make this connection by constructing absorptive capacity at the firm level as a component of absorptive capacity at the provincial level.

The main concern of the article is the impact of absorptive capacity on the link of foreign direct investment with host nations. It seems true that benefits from FDI to host countries vary depending on absorptive capacity (Alfaro, Chanda, \& Kalemli-ozcan, 2004; Borensztein, De Gregorio, \& Lee, 1998; Carkovic \& Levine, 2005; Durham, 2004; Fu, 2008). However, each researcher scrutinizes absorptive capacity from a different perspective and via different proxies. Some use human capital while others use financial development or the level of openness to represent absorptive capacity. We believe that absorptive capacity should be multidimensional. Therefore, this article attempts to review substantial studies on the topic so as to highlight several dimensions, including institutions, infrastructure, the level of openness, human capital, and financial development. Apart from these, the absorptive capacity of domestic firms is also vital, hence the article uses it as the sixth dimension. The construction of absorptive capacity with six components is tested by applying the single-factor measurement model.

Then, we test the impact of absorptive capacity on the relationship between FDI and economic growth on the case study of Vietnam, where FDI has played an essential role in boosting the development. The article runs a regression with instrumental variables for 63 provinces in Vietnam from 2007 to 2015. The key finding is that among the six dimensions only four play a moderating role in the link between FDI and growth: infrastructure, openness, human capital, and the absorptive capacity of domestic firms.

The article is constructed as follows. The second part contains a literature review of existing studies on the topic of absorptive capacity at provincial or national level. We develop six hypotheses based on the review. The third part describes the techniques used to test the construction of the absorptive capacity of provinces and the method to estimate the effect 
of absorptive capacity on the relationship between FDI and provincial development. Furthermore, this part discusses the methodology to construct the absorptive capacity of domestic firms, followed by results and discussion. The article ends with a conclusion.

\section{LITERATURE REVIEW AND HYPOTHESES DEVELOPMENT}

It is well known that FDI can impact host countries directly and indirectly, but the potential benefits cannot automatically convert into positive impacts without domestic capability. The term absorptive capacity became widespread after the research by Cohen and Levinthal $(1989,1994,1990)$. Therefore, we may consider the concept of those authors as a root definition of absorptive capacity. After that, there appeared substantial studies on the topic of FDI absorptive capacity at all levels. Some authors focused on absorptive at the firm level (Cohen \& Levinthal, 1994; Martinkenaite \& Breunig, 2015; Szulanski, 1996; Tu, Vonderembse, Ragu-Nathan, \& Sharkey, 2006; Vu, 2018; Zahra \& George, 2002) by stating that firms need certain levels of absorptive capacity to improve their performance. Other articles looked at absorptive capacity at the provincial or national level. Although we examine the importance of absorptive capacity at the macro level, we still consider the firm aspect by creating the absorptive capacity of firms in provinces as the component of absorptive capacity at the provincial level.

Basically, the approach of this article on the absorptive capacity at the macro level is similar to the approach of Schillaci et al. (2013). Schillaci et al. (2013) define the absorptive capacity of territory as "the ability of a Region to identify, assimilate, and exploit external knowledge" (p. 109). They develop their definition from that of Cohen and Levinthal who consider the absorptive capacity as "the ability of firms to recognize the value of new, external information, assimilate it, and apply it to commercial ends"(Cohen \& Levinthal, 1990, p. 128). In their study, Schillaci et al. (2013) claim that the absorptive capacity of territory includes three determinants: human skills, research and development (R\&D), expenditure, and knowledge gatekeepers. They partly refer to the importance of firms when discussing knowledge gatekeepers, but the role of absorptive capacity of firms is quite blurred. Therefore, we make a contribution by adding the role of absorptive capacity of firms into the group of absorptive capacity components at the macro level. In fact, our idea bases on the root argument of Cohen and Levinthal (1990). They argue that the absorptive capacity of an organization depends on the absorptive capacity of individuals, but it cannot simply be a sum of individuals' capacity. There are other factors that could determine the absorptive capacity of the organization, including its structure or environment. Consequently, Cohen and Levinthal (1990) claim that the absorptive capacity "depends on the individuals who stand at the interface of either the firm and the external environment or at the interface between subunits within the firm" (Cohen \& Levinthal, 1990, p. 132). Based on it, we propose that absorptive capacity of a province depends on the absorptive capacity of firms and other factors, in which the role of firms is similar to the role of individuals in the absorptive capacity of firms.

Firstly, we should begin with how to measure the absorptive capacity of a firm. Several studies examine the internal aspects of absorptive capacity in firms. These articles underline the importance of internal knowledge, prior knowledge and the mechanism of knowledge transfer within a firm (Szulanski, 1996; Tu et al., 2006; Zahra \& George, 2002). 
From another perspective, some studies focus on the inter-firm aspects of absorptive capacity. Lane and Lubatkin (1998) indicate that the absorptive capacity of firms can be relative, and it depends on whether firms can find good partners or not. Lane and Lubatkin (1998) also believe that if a "student firm" has a chance to cooperate with "teacher firms," which share some common characteristics, this student firm can learn quicker and more effectively. Similarly, Dyer, and Singh (1998) argue that taking full advantage from partnerships with more advanced firms can boost a firm's performance. Vu (2018) argues that the scope of firms' absorptive capacity is broad, and it might be limited only to separate consideration of intra-firm and inter-firm aspects. Therefore, it is better to combine the two aspects. The intra-firm aspect is the internal capability of a firm, while the inter-firm aspect is the gap between this firm and other firms in the same industry. Then, the absorptive capacity of a firm can be measured by the gap in capability between this firm and the best firms in the same industry. Hence, we based on the method of Vu (2018) to measure the capability of a firm by estimating persistent (in)efficiency. Persistent (in)efficiency is a component of technical efficiency and a long-term factor that only changes if there occur big changes in industry policy or management structure of a firm (Kumbhakar, Lien, \& Hardaker, 2014). Hence, persistent (in)efficiency is a firm-specific factor that can be a good explanation of internal capacity $(\mathrm{Vu}, 2018)$. Noticeably, this measurement is more applicable than other proxies of absorptive capacity, including R\&D intensity (Behera, 2015; Tsai, 2001), human capital (Martinkenaite \& Breunig, 2015), or R\&D expenditure (Girma, Gorg, \& Pisu, 2008). The reason is that persistent efficiency is estimated from production function, which only requires basic information including output, labour, capital, and other intermediate goods. This type of information is easier to access than information about related R\&D data. Especially in the case of developing countries - including Vietnam - data on R\&D is insufficient and unreliable. This article based on the method of $\mathrm{Vu}$ (2018) on the measurement of absorptive capacity at the firm level with some amendments. The amendments are discussed in the next section.

Secondly, apart from absorptive capacity at the firm level, we should indicate other components that could determine the absorptive capacity at the provincial level. There are substantial studies on absorptive capacity and, consequently, its various proxies. This article takes from theories of absorptive capacity. Nguyen, Duysters, Patterson, and Sander (2009) put forward the model of FDI photosynthesis, in which they divided FDI absorbability into two stages: "one is to bring FDI projects to practice and the next one is to convert the benefit of FDI into host country's competences" (Nguyen et al. 2009, p.5). After attracting FDI, host countries need sufficient absorptive capacity to ensure that the gap between registered capital and disbursement is as small as possible. At this stage, host countries might gain from the direct benefit of FDI, such as physical capital, job creation, or contribution of FDI to national output. These are the direct effects of FDI on host countries, and they are visible. However, it is obvious that recipients expect more than these direct benefits. Host countries certainly expect that foreign investors create spillover effects (indirect effect) through technology or know-how diffusion. And at this point, each country will differ from another in terms of the benefits gained from FDI. Countries with a better absorptive capacity will gain more than countries with weak absorptive capacity. Nguyen et al. (2009) identify six determinants of absorptive capacity, including the capacity of firms, human capital, technology level, institutions, infrastructure, and financial sys- 
tem. The authors consider six components of a plant-like photosynthesis process, in which institutions and technology are the ground, infrastructure and financial system are the body, while firms and human capital are tree leaves. From another perspective, Schillaci et al. (2013) claim that the absorptive capacity of a territory includes three determinants: human skills, R\&D expenditure, and knowledge gatekeepers. Schillaci et al. (2013) argue that some organizations in one territory have to play a key role as knowledge gatekeepers. These organizations can bridge external knowledge and regional innovation system. Generally, it seems that the absorptive capacity of an entity - a province, region, or country cannot be captured by a single measurement. Therefore, our study reviews various studies from Scopus and the Web of Science on this topic and reveals that there are five main components of absorptive capacity at provincial or national level.

\section{Institutions}

Hodgson (2006) defines institutions "as systems of established and prevalent social rules that structure social interactions" (Hodgson, 2006, p. 2) and this definition can be either inclusive institutions or extractive institutions. Acemoglu, Johnson, and Robinson (2005) argue that institutions might be important for economic outcomes, because they could influence the structure of property rights and the presence of market perfection or economic incentives in society. Acemoglu, Johnson, and Robinson (2005) refer this to an inclusive economic institution, as they believe that institutions can help to allocate production inputs efficiently. On the other hand, exclusive institutions - including political ones might hamper economic growth of nations by only focusing on the interest of specific political groups (Acemoglu et al., 2005). Therefore, institutions can be an influencing factor of development, especially for the international business field. Cantwell, Dunning, and Sarianna (2010) and Dunning and Lundan (2008) agree that institutions are becoming increasingly important in shaping the operation of multinational enterprises (MNCs) and their externalities. In the case of Vietnam, Meyer and Nguyen (2005) argue that institutional conditions are important, as they are a factor that can influence entry strategy and location decisions of foreign investors. More specifically, incumbent state-owned enterprises may impact the institutional framework and then encourage foreign counterparts to cooperate with them. Furthermore, foreign firms tend to locate in provinces where local institutions allow them to access more easily natural resources.

H1: Institutions affect the impact of FDI on economic development.

\section{Infrastructure}

Infrastructure refers to public services, including health services, schooling, energy infrastructure, transportation, and telecommunication networks. There is evidence that the positive impact of FDI is contingent on the development of infrastructure of host countries (Yamin \& Sinkovics, 2009). The authors argue that inadequate infrastructure in some lessdeveloped countries (LDCs) hampers the potential effect of FDI. In contrast, good infrastructure can increase FDI-related firm productivity by reducing production costs and consequently create more spillovers for host countries (Alsan, Bloom, \& Canning, 2006). Similarly, Dunning (2002) and Dunning and Narula (2004) conclude that emerging countries can absorb the benefits of FDI if they possess certain levels of infrastructure. Therefore, we expect that infrastructure can facilitate spillovers from FDI. 
H2: Infrastructure affects the impact of FDI on economic development.

\section{Openness}

The importance of the level of openness was first discussed by Bhagwati (1978). He hypothesizes that the impact of FDI in host countries varies following the imports or exports strategy. More specifically, if a host country follows the more open policy, she will be more likely to benefit from spillovers of FDI. The main incentive for FDI is that the openness regime may provide a combination of cheap production costs and an export-promoting orientation. Various researchers support the argument of Bhagwati (Balasubramanyam, Salisu, \& Sapsford, 1996; Beugelsdijk, Smeets, \& Zwinkels, 2008; Carkovic \& Levine, 2005; Kohpaiboon, 2003; Lai et al., 2006) and test the "Bhagwati hypothesis" in empirical studies at the national and inter-country level. Generally, the level of openness can impact the relationship between FDI and economic growth of host countries.

H3: The level of openness affects the impact of FDI on economic development.

\section{Human Capital}

One of the most important roles of FDI is to create the process of technology diffusion. MNCs are supposed to have more advanced knowledge that allows them to introduce new production inputs at a cheaper price (Borensztein et al., 1998). However, the application process might require a sufficient level of recipients' human capital. If this level is low, it is unlikely that host countries can absorb and apply advanced knowledge into practice. Therefore, human capital can be a detrimental factor of less developed or developing countries (Nelson \& Phelps, 1966). Nevertheless, if host countries possess a good level of human capital, it can facilitate the effect from FDI to growth (Baharumshah \& Almasaied, 2009; Borensztein et al., 1998; Zhang, 2001).

H4: The level of human capital affects the impact of FDI on economic development.

\section{Financial Development}

The lack of financial market development can hinder host nations from making use of FDI spillover effects. A well-functioning financial market can lower transaction costs and allocate capital effectively. Moreover, it can provide domestic firms with financial sources to finance their activities. FDI firms are more advanced and they might set specific requirements on technology for their domestic partners. Hence, the domestic firms need support from the financial market because their internal funding may be insufficient to buy new machines or recruit high-skilled workers and managers. Otherwise, they are unable to cooperate with their foreign counterparts, so the market cannot absorb positive spillovers from FDI (Alfaro et al., 2004). Many authors share this idea (Baharumshah \& Almasaied, 2009; Beugelsdijk et al., 2008; Carkovic \& Levine, 2005; Durham, 2004; Hermes \& Lensink, 2003) and conduct empirical studies to test the role of financial markets, but the results are mixed.

H5: The level of financial development affects the impact of FDI on economic development. 


\section{The Absorptive Capacity of Domestic Firms}

Bell and Pavitt (1992) state that accumulating technological capacity is essential for developing countries and the firms play a central role in this process. Most technological transfers occur at the firm level, and the level of technological accumulation is a prerequisite for this transfer. The absorptive capacity of domestic firms is examined by substantial studies, due to its moderating role in the relationship between FDI and economic development. It is obvious that the presence of FDI firms can create positive spillovers, but if domestic firms are not capable to learn new knowledge, they might never take advantage of FDI externalities. However, major studies deal with this issue at the firm level, while we believe that it should also be a vital factor at the macro level. Therefore, this factor is constructed at the provincial level and then the study attempts to explore its impact on FDI spillovers.

H6: The absorptive capacity of domestic firms affects the impact of FDI on Vietnamese economic development.

In the case of Vietnam, there are several studies on the topic of the impact of FDI at both firm-level and provincial level. At the firm level, Anwar and Nguyen (2010a) study the importance of FDI-generated spillovers at the firm level in Vietnam between 1995 and 2005 and conclude that these spillovers play a moderating role in the link from backward linkages to the performance of firms in the manufacturing sector. Le and Pomfret (2011) examine how FDI spillovers can affect the productivity of Vietnamese firms. They find that the vertical spillover is positive but the horizontal one is negative. At the provincial level, $\mathrm{Vu}(2008)$ focuses on the indirect effect of FDI at the sectoral level and the author finds the positive impact of FDI on labour productivity and economic growth in Vietnam. However, the effect varies across sectors. Vu, Gangnes, and Noy (2008) examine the impact of FDI on growth across the economic sector of Vietnam in comparison with China. The authors find the positive effect of FDI for both nations, but the effect varies in different sectors. Thang, Pham, and Barnes (2016) examine the impact of inter-firm factors on spillovers from foreign firms to domestic firms in Vietnam from 2000 to 2005 and conclude that the gap between foreign and direct firms can negatively affect productivity spillovers. Anwar and Nguyen (2010b) examine the impact of FDI on economic growth in Vietnam from 1996 to 2005. Their study finds that FDI and economic growth mutually affect each other, while the link from FDI to growth can be further facilitated by investing more in education and training. Generally, the impact of FDI and the role of absorptive capacity is not a new topic, but the majority of authors only focuses on this issue at the firm level or the provincial level in separation. Therefore, this article contributes to connecting absorptive capacity at the firm level to absorptive capacity at the provincial level by modifying the method of $\mathrm{Vu}$ (2018) and constructing the absorptive capacity of firms within provinces. Moreover, the construction of the absorptive capacity of six components is tested with confirmatory factor analysis.

\section{MATERIAL AND METHODS}

\section{Methodology}

This article reviews various studies to argue that the absorptive capacity of a province includes six components, which are institutions, financial development, human capital, openness, the absorptive capacity of domestic firms, and infrastructure. Based on this ar- 
gument, we must test whether the six components are valid for the construction of absorptive capacity by using confirmatory factor analysis (CFA). In this model, absorptive capacity is a latent unobservable variable, constructed by six observed variables. This method helps to bring the first idea about the significance and impact of each component on absorptive capacity. Moreover, the method tests if the data can be consistent with the hypotheses. The article considers panel data from 2007 to 2015 as one extended cross-sectional data and then apply single-factor measurement model. Then, the estimated model can be presented as follows:

$$
\begin{gathered}
\ln (H C)=\alpha_{1}+A C * \beta_{1}+\varepsilon_{1} \\
\ln (F D)=\alpha_{2}+A C * \beta_{2}+\varepsilon_{2} \\
\ln (I N S)=\alpha_{3}+A C * \beta_{3}+\varepsilon_{3} \\
\ln (O P N)=\alpha_{4}+A C * \beta_{4}+\varepsilon_{4} \\
\ln (I N F R)=\alpha_{5}+A C * \beta_{5}+\varepsilon_{5} \\
\ln (A C P)=\alpha_{6}+A C * \beta_{6}+\varepsilon_{6}
\end{gathered}
$$

Human capital (HC), financial development (FD), institutions (INS), openness (OPN), infrastructure (INFR), and absorptive capacity of domestic firms in provinces (ACP) are six components of absorptive capacity (Table 2), while AC is the latent variable of absorptive capacity, $\varepsilon$ is error term, and $\beta$ is the coefficient that indicates the path from latent variable and its components. The CFA model is used to check the validity of the statement that is absorptive capacity of provinces include six dimensions. Moreover, when conducting CFA, we treated the database as an extended cross-section, so the results from CFA are not included in the next regression.

After evaluating the measurement of the absorptive capacity of provinces, we continue with another regression techniques. The study establishes a production function with FDI as one independent variable to test the hypotheses. The Cobb-Douglas production function at the provincial level is as following:

$$
Y_{i t}=A_{i t}\left(K_{i t}\right)^{\alpha}\left(L_{i t}\right)^{\beta}
$$

Where $i$ is province $i, t$ is time $t, Y$ is output of province, $K$ is capital and $L$ is the labour of province. $\alpha$ and $\beta$ are the elasticity of $K$ and $L$, while $A$ is total factor productivity (TFP). After dividing both sides by $L_{-}$it, the author takes a logarithm and then equation (2) becomes:

$$
\ln \left(Y_{-} i t / L_{-} i t\right)=\ln \left(A_{-} i t\right)+\alpha * \ln \left(K_{-} i t / L_{-} i t\right)
$$

The model assumes that $\alpha+\beta=1$.

The interest of this article is in the indirect effect of FDI, so an impact of FDI is examined via TPF. It implies that $A$ is a function of FDI and other factors (Huang, Liu, \& Xu, 2012). Consequently, we obtain:

$$
A_{i t}=f\left(F D I_{i t}, A C_{i t}\right)=F D I_{i t}{ }^{\beta} * A C_{i t}{ }^{\theta} * e^{\varepsilon_{i t}}
$$

Replace (3) into (2), which gives:

$$
\ln \left(\frac{Y_{i t}}{L_{i t}}\right)=\beta * \ln \left(F D I_{i t}\right)+\alpha * \ln \left(\frac{K_{i t}}{L_{i t}}\right)+\theta * \ln \left(A C_{i t}\right)+\varepsilon_{i t}
$$

Then, we examine the role of absorptive capacity by creating interaction terms between $A C$ and FDI: 


$$
\begin{aligned}
\ln \left(\frac{Y_{i t}}{L_{i t}}\right)= & \beta \cdot \ln \left(F D I_{i t}\right)+\alpha \cdot \ln \left(\frac{K_{i t}}{L_{i t}}\right)+\theta \cdot \ln \left(A C_{i t}\right)+ \\
& +\delta \cdot \ln \left(F D I_{i t}\right) \cdot \ln \left(A C_{i t}\right)+\varepsilon_{i t}
\end{aligned}
$$

in which $\varepsilon_{-}$it is the random disturbance that is normally distributed. Notably, the dimensions of absorptive capacity include infrastructure, institutions, financial development, human capital, and provincial absorptive capacity. All the variables can be considered as endogenous ones. Therefore, the study applies the Instrumental Variables method in which the instrument variables are lag of themselves. The lag level is identified after testing for endogeneity. Furthermore, the use of a fixed effect or random effect model is necessary to test to fit the used model to the database.

Table 1. Dimensions of absorptive capacity

\begin{tabular}{|l|l|l|}
\hline \multicolumn{1}{|c|}{ AC determinants } & \multicolumn{1}{|c|}{ Proxy } & \multicolumn{1}{c|}{ Source } \\
\hline HC (Human capital) & $\begin{array}{l}\text { Ratio of trained workers over 15 y.o. to } \\
\text { labour force }\end{array}$ & $\begin{array}{l}\text { Vietnam General Statistic } \\
\text { Office }\end{array}$ \\
\hline $\begin{array}{l}\text { FD (Financial Develop- } \\
\text { ment) }\end{array}$ & Market capitalization & $\begin{array}{l}\text { State Securities Commis- } \\
\text { sion of Vietnam }\end{array}$ \\
\hline INST (Institutions) & Provincial Competitiveness Index & PCI annual report \\
\hline OPN (Trade Openness) & (Exports + Imports)/GDP & Provincial Statistics Office \\
\hline INFR (Infrastructure) & $\begin{array}{l}\text { Km of road used for freight and passen- } \\
\text { ger transport per cap }\end{array}$ & $\begin{array}{l}\text { Vietnam General Statistic } \\
\text { Office }\end{array}$ \\
\hline $\begin{array}{l}\text { ACP (Absorptive Capacity } \\
\text { of Domestic Firms) }\end{array}$ & $\begin{array}{l}\text { Based on the absorptive capacity of do- } \\
\text { mestic firms at firm level }\end{array}$ & \\
\hline
\end{tabular}

Source: own study.

Proxies for infrastructure, institutions, financial development, and human capital appear in Table 1. All of them are secondary data provided by the provincial statistics office. Only the proxy for absorptive capacity at the provincial level is constructed based on the method of $\mathrm{Vu}$ (2018) with a few slight modifications. Vu (2018) considered the absorptive capacity of a firm to be a gap between its persistent inefficiency and the best FDI firm in the same industry (for details on persistent inefficiency, see $\mathrm{Vu}, 2018$ ). However, it is better to consider the gap between the persistent inefficiency of a firm and the average one of FDI firms, because the spillover effect not only comes from a top FDI firm but also from other FDI firms in the same industry. Consequently, the absorptive capacity of a single domestic firm is:

$$
A C_{q j t}=\frac{D P E_{q j t}}{\overline{F P E_{\mathrm{J}}}} \times 100
$$

in which $A C_{q j t}$ is the absorptive capacity of the domestic firm q in the industry $\mathrm{j}$ in time $\mathrm{t}$, and $D P E_{q j t}$ presents the persistent efficiency of the domestic firm q in industry $\mathrm{j}$ in time t. $\overline{F P E_{J}}$ is the mean value of the persistent efficiency of foreign firms in the sector $\mathrm{j}$ over the years.

Based on the absorptive capacity of domestic firms, the absorptive capacity of provinces is constructed by taking the mean value of all domestic firms within one territory. It is best if the territory is divided into provinces. However, the database does not cover all provinces in 
Vietnam, the study calculates the absorptive capacity at the regional level. There are six regions in Vietnam classified based on geographical and economic proximity. Therefore, the absorptive capacity of provinces is proxied by the absorptive capacity at the regional level.

Notably, we seek to examine the impact of FDI indirect effect (spillover effects). Therefore, it is best if the FDI variable here could measure spillover effects. Unfortunately, the database to calculate spillover effects at the provincial level is unavailable. Therefore, the article uses the stock of FDI in provinces with the expectation to capture both the direct and indirect effect of foreign capital.

\section{Data}

The study examines six hypotheses in the case of Vietnam at the provincial level from 2007 to 2015 . We selected 63 provinces in Vietnam grouped into six regions. Therefore, there are 504 observations in total. Notably, the study uses lag value as instruments of endogenous variables. It implies that it must trade between the number of observation and the validity of instruments.

In equation (4), $Y_{i t}$ is real gross domestic product of province i at time t. $L_{i t}$ is total labour of province i at time t. Hereafter $Y_{i t} / L_{i t}$ is mentioned as GDP of province i. FDI is stock of FDI capital of province $i$ at time $t$. This is an accumulation of FDI capital like every year at the end of December. $K_{i t}$ is the stock of capital calculated by applying the perpetual inventory method. The method requires the availability of investment of province i, collected from provincial statistic offices. Let us notice that the investment equals the investment of private sector plus the investment of public sector. Hereafter $K_{i t} / L_{i t}$ is mentioned as the capital stock of province i. All these variables are collected from the annual provincial statistics books.

$A C_{i t}$ are dimensions of absorptive capacity of province $\mathrm{i}$ at time $\mathrm{t}$, including institutions, financial development, human capital, infrastructure, openness, and the absorptive capacity of domestic firms. Institutions are proxied by the provincial competitiveness in$\operatorname{dex}(\mathrm{PCI})$, developed by the Vietnam Chamber of Commerce and Industry. It measures the quality of provincial governance in creating a business environment (for more, please check the eng.pcivietnam.org/about/about-pci). In fact, the element of institutions make a broad definition, and it is never easy to find a single proxy for it. However, we believe that the $\mathrm{PCl}$ can be an acceptable proxy because this is a province-specific index, which differentiates the business environment of each province. It reflects economic governance areas which have an impact on the development of the private sector. It covers several important formal and informal factors in Vietnam including information transparency, land access, and policy bias. More importantly, the $\mathrm{PCl}$ has an impact on the policymaking process, because it has been included in the current Governmental Resolution 02/NQ-CP dated $01 / 01 / 2019$ on the solutions to improve the business environment and national competitiveness in 2019, toward 2021. In fact, this index is used to proxy for institutions of Vietnam provinces in some studies (Malesky \& Taussig, 2009; Thang, Pham, \& Barnes, 2016). The financial development of a province is represented by the market capitalization of headquarters of listed companies in 63 provinces. In fact, it would be better if we could use other proxies, including the ratio of savings to provincial GDP, the ratio of credit to provincial GDP, and the ratio of Money supply (M2) to provincial GDP. However, these proxies are not publicly available, so we must use market capitalization of listed companies to proxy for the development of the financial market. The argument is that companies 
listed in the stock market must meet some requirements and make annual reports about their operations. Therefore, these companies are more transparent than unlisted companies, and they need to access official capital sources rather than sources under the table. Thus, we argue that provinces with more listed companies are more attractive for incoming investors, so are likely to develop more than others. It might be a result of concentration impact. Human capital is measured by the ratio of trained workers over 15 years old to the total labour of a province. By trained workers, we mean those who have been trained to meet minimum requirements of jobs, might have or not have certificates. Infrastructure is proxied by $\mathrm{km}$ of road used for freight and passenger transport per capita. Openness is the ratio of imports and exports to GDP. Finally, provincial absorptive capacity is calculated by Vu's (2018) method, with our modification. The monetary variables are real values and in million USD. All variables are in logarithm transformation. The distribution of these variables appear in Appendix B.

\section{RESULTS AND DISCUSSION}

First of all, the CFA results show that the hypothesis that the absorptive capacity of a province includes six components is valid. The proposed model of six components of absorptive capacity is confirmed by several tests. The first one is a goodness-of-fit test and the insignificant result implies that the model fits well. The Chi-square (4) is 6.292 and its significant level is 0.1784 , so the proposed model fits data well. The second important fit statistic is the root mean squared error of approximation (RMSEA). The value of this test close to zero represents a good fit and the cut-off value is 0.08 . The reported RMSEA in this case is 0.032 , which indicates a good model. Furthermore, the comparative fit index (CFI) and Tucker-Lewis index of the model is 0.997 and 0.989 respectively which are more than the cut-off value of 0.95 . Finally, the value of standardized root mean square residual (SRMR) is 0.017 - which is smaller than the cut-off value of 0.08 - thus confirming that the discrepancy between the sample covariance matric and the model covariance matrix is quite small. Based on the fit tests, we may say that the proposed measurement model of absorptive capacity is valid and fits data well.

Regarding the regression coefficient in the CFA model (Figure 1). All coefficients are statistically significant at $0.1 \%$ level, which shows that they certainly contribute to the construction of absorptive capacity. Let us note that all coefficients (factor loadings) are fully standardized and they can be interpreted as correlations. For example, the path from the latent variable to the component Openness is 0.74 . It means that a $1 \%$ increase in absorptive capacity is associated with $0.74 \%$ increase in the Openness component. Differently, the coefficient can be interpreted as variance of a component after taking square. In case of Openness, $54.76 \%(0.74 * 0.74)$ of variance of the Openness component can be explained by the latent variable and, respectively, $46.34 \%$ variance of Openness is explained by another factor, not by absorptive capacity. From the CFA regression results, we see that Openness, Financial Development and Infrastructure are the best ones among the six components. Although the loading factors of components are not high and there might be some arguments about the cut-off value of loading factors, the author believes that the key point is the significance of coefficients and the goodness fit of the model. It is because the proposed model is built based on literature review and these components have been widely used. Therefore, it is possible to state that the single factor measurement model 
confirms that the construction of absorptive capacity at the provincial level is reliable and, importantly, the absorptive capacity of domestic firms is the component that significantly contributes to the construction of provinces' absorptive capacity.

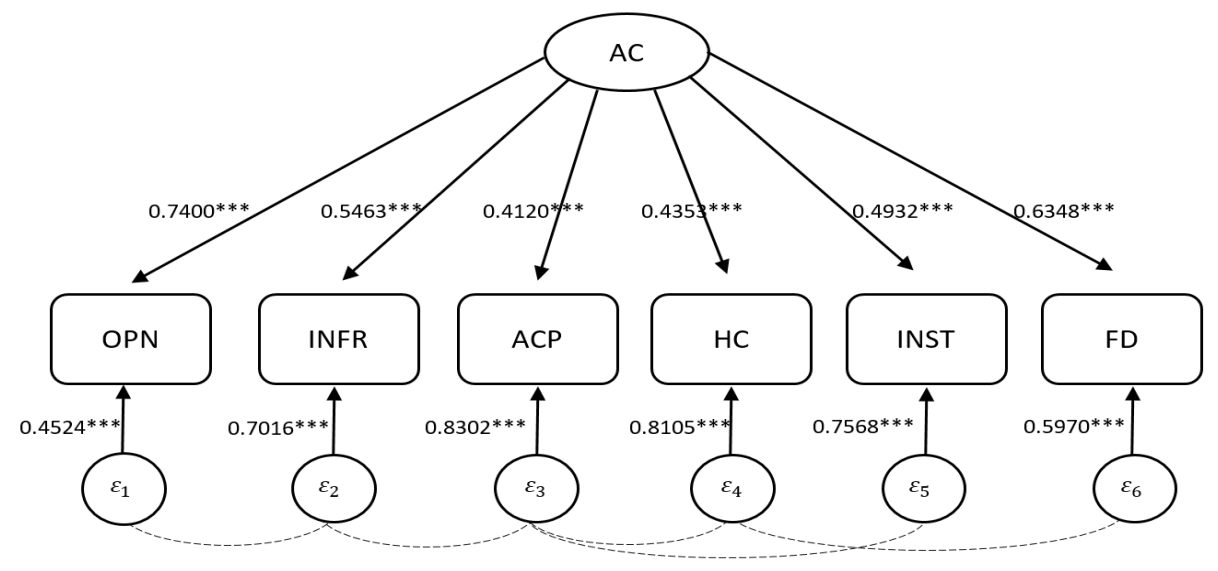

Figure 1. Results from the single-factor measurement model

$* * *$ statistically significant at $0.1 \%$ level Source: own elaboration.

Then, the study estimates the impact of absorptive capacity on the link from FDI to the economic performance of 63 provinces in Vietnam. Before running regression, it needs to conduct several tests to identify the validity of the econometric model. The Hausman test shows that - in the case of the database of Vietnam - the random effect model is preferable. It means the assumption is that covariates and error term are not correlated. Due to the potential endogeneity of independent variables, we use their lag at the second level as instrument variables after taking a test on autocorrelation. It seems that autocorrelation occurs at the first level, so the use of lag at the second level is more appropriate (Arellano-Bond test). Next, the robustness and validity of these instrument variables are tested with other methods (the Anderson-Rubin Wald test, the Stock-Wright test, the Sanderson-Windmeijer test). Generally, the necessary tests show that the model is robust and valid (Appendix A).

Consequently, we apply the G2SLS random effect IV regression and clusters for 63 provinces to correct heteroscedasticity and autocorrelation. Firstly, we regress the equation (4) to examine the main effects of FDI and other independent variables on the performance of provinces.

From the first column of Table 2, we can see the key point is that FDI positively influences provincial GDP. A $1 \%$ increase in the stock of FDI may lead to a $0.052 \%$ increase in GDP per worker. The coefficient of FDI is statistically significant at $5 \%$ level. Moreover, the capital stock per worker also has a positive and significant impact on provincial GDP per worker at a $0.1 \%$ level. Turning to other variables, all coefficients are positive, which implies that they might have positive effects on the performance of provinces. Nevertheless, in the case of Vietnam, only human capital, openness, infrastructure, and the ab- 
sorptive capacity of firms are statistically significant. The impacts of financial development and institutions in Vietnam are unable to be claimed in this study. Among the four significant dimensions of absorptive capacity, the magnitude of ACP is the biggest. It implies that the capability of firms is essential for the development of a province. If the absorptive capacity of domestic firms in one province increases by $1 \%$, GDP per worker of this province can rise by $1.0869 \%$. This finding might be vital for policymakers at the provincial level. The operation and development of domestic firms should be prioritized. Moreover, the level of openness, infrastructure, and human capital also play an important role in boosting provincial economies with coefficients of $0.1097,0.1791$, and 0.0166 , respectively. The article takes one more step to see the role of ACP by excluding this dimension from the model and then comparing the explanatory power of the two empirical models. The adjusted R-square of model 1 is 0.7034 . Then, the adjusted $\mathrm{R}$-square of the model when excluding ACP is only 0.67881 (we offer model's results without ACP upon request). This implies that the exclusion of ACP may negatively impact the model. Consequently, the role of ACP is confirmed empirically.

However, the main interest of the article is the impact of absorptive capacity dimensions on the link from FDI to provincial GDP. Therefore, the interaction terms between these dimensions and FDI are created. The most important points now are the coefficients of the interaction terms from column 2 to 7 . The results show that among the six dimensions of absorptive capacity, only four impacts the relationship between FDI and provincial GDP. In the second column, the coefficient of the interaction term between FDI and infrastructure is 0.0912 , statistically significant at $10 \%$ level. We may interpret it that infrastructure can affect provincial GDP through the stock of FDI, or that the effect of FDI on provincial GDP depends on the value of infrastructure. Let us note that the main effect of FDI conditional on infrastructure now is $0.0020+0.0912 * \operatorname{Ln}(I N F R)$. The mean value of $\operatorname{Ln}($ INFR) is 0.7447 , hence the main effect of FDI is now $0.0020+0.0912 * 0.7447=0.0698$. The number of 0.0698 is now interpreted differently. It means that in case a province has a mean level of infrastructure, a $1 \%$ increase in FDI leads to a $0.0698 \%$ increase in GDP of this province.

The moderating role of the level of openness appears in column 3 . The coefficient of the interaction term is positive and statistically significant at $0.1 \%$ level. It implies that the provinces which actively participate in trading activities can gain more from FDI spillovers. Noteworthy, the coefficient of $\operatorname{Ln}(\mathrm{FDI})$ is not statistically significant at the moment. This does not mean that FDI does not have an impact on provincial GDP. It only indicates that FDI does not influence provincial GDP if the level of openness is zero. Obviously, this rests beyond the interest of our study, hence the insignificance of $\operatorname{Ln}(F D I)$ is unimportant. Instead, the main effect of FDI now is $0.0061+0.0426 * 1.4085=0.0661$. The interpretation is that a $1 \%$ increase in the stock FDI leads to a $0.0661 \%$ increase in GDP of a province with an average level of openness. Similar is the role of human capital in column 4. The statistical significance of the interaction term proves that skilled workers can facilitate the impact of FDI spillover to provincial development. Finally, the absorptive capacity of domestic firms also plays a vital role in the relationship between FDI and provincial growth. The positive and significant coefficient of the interaction term in column 6 confirms this argument. Conversely, although the coefficients of interaction terms between FDI, institutions, and financial development variables are positive, their statistical insignificance shows us that institutions and financial markets seem not so important as other dimensions of absorptive capacity in the case of Vietnam. 
Table 2. Regression results

\begin{tabular}{|c|c|c|c|c|c|c|c|}
\hline & Model 1 & Model 2 & Model 3 & Model 4 & Model 5 & Model 6 & Model 7 \\
\hline $\operatorname{Ln}(Y / L)$ & $\begin{array}{c}\text { Coefficient } \\
\text { (p-value) }\end{array}$ & $\begin{array}{c}\text { Coeffi- } \\
\text { cient } \\
\text { (p-value) }\end{array}$ & $\begin{array}{c}\text { Coefficient } \\
\text { (p-value) }\end{array}$ & $\begin{array}{c}\text { Coeffi- } \\
\text { cient } \\
\text { (p-value) }\end{array}$ & $\begin{array}{c}\text { Coefficient } \\
\text { (p-value) }\end{array}$ & $\begin{array}{c}\text { Coefficient } \\
\text { (p-value) }\end{array}$ & $\begin{array}{c}\text { Coeffi- } \\
\text { cient } \\
\text { (p-value) }\end{array}$ \\
\hline $\operatorname{Ln}(\mathrm{FDI})$ & $\begin{array}{l}0.0527^{*} \\
(0.0336)\end{array}$ & $\begin{array}{c}0.0020 \\
(0.9642)\end{array}$ & $\begin{array}{c}0.0061 \\
(0.7944)\end{array}$ & $\begin{array}{c}0.0175 \\
(0.5440)\end{array}$ & $\begin{array}{c}0.0123 \\
(0.7500)\end{array}$ & $\begin{array}{l}0.0971 * \\
(0.0122)\end{array}$ & $\begin{array}{c}-0.6398 \\
(0.6677)\end{array}$ \\
\hline $\operatorname{Ln}(\mathrm{INFR})$ & $\begin{array}{c}0.1791+ \\
(0.0671)\end{array}$ & $\begin{array}{c}-0.4690 \\
(0.1302)\end{array}$ & $\begin{array}{l}0.1927^{*} \\
(0.0366)\end{array}$ & $\begin{array}{l}0.1901+ \\
(0.0555)\end{array}$ & $\begin{array}{l}0.1790+ \\
(0.0506)\end{array}$ & $\begin{array}{l}0.1867+ \\
(0.0524)\end{array}$ & $\begin{array}{c}0.3465 \\
(0.3249)\end{array}$ \\
\hline $\operatorname{Ln}(K / L)$ & $\begin{array}{c}0.2172^{* * *} \\
(0.0000)\end{array}$ & $\begin{array}{l}0.2013+ \\
(0.0761)\end{array}$ & $\begin{array}{c}0.1974 * * * \\
(0.0000)\end{array}$ & $\begin{array}{l}0.1975+ \\
(0.0884)\end{array}$ & $\begin{array}{c}0.2112^{* * *} \\
(0.0000)\end{array}$ & $\begin{array}{c}0.1826 * * * \\
(0.0000)\end{array}$ & $\begin{array}{c}0.3312 \\
(0.5196)\end{array}$ \\
\hline $\operatorname{Ln}(\mathrm{HC})$ & $\begin{array}{l}0.0166^{*} \\
(0.0277)\end{array}$ & $\begin{array}{c}0.0095 \\
(0.4197)\end{array}$ & $\begin{array}{l}0.0139 * \\
(0.0442)\end{array}$ & $\begin{array}{c}0.0112 \\
(0.2229)\end{array}$ & $\begin{array}{c}-0.0083 \\
(0.6246) \\
\end{array}$ & $\begin{array}{l}0.0169 * \\
(0.0148) \\
\end{array}$ & $\begin{array}{c}-0.0210 \\
(0.7029)\end{array}$ \\
\hline $\operatorname{Ln}(A C P)$ & $\begin{array}{l}1.0869+ \\
(0.0694)\end{array}$ & $\begin{array}{c}1.1424 \\
(0.3114)\end{array}$ & $\begin{array}{c}1.3874^{* *} \\
(0.0090)\end{array}$ & $\begin{array}{c}0.8828 \\
(0.1903)\end{array}$ & $\begin{array}{c}0.9053 \\
(0.1484)\end{array}$ & $\begin{array}{c}-2.5501 \\
(0.1179)\end{array}$ & $\begin{array}{l}-1.8990 \\
(0.8215)\end{array}$ \\
\hline $\operatorname{Ln}(\mathrm{INS})$ & $\begin{array}{c}0.2136 \\
(0.7300)\end{array}$ & $\begin{array}{c}0.1120 \\
(0.9003)\end{array}$ & $\begin{array}{c}0.3581 \\
(0.5652)\end{array}$ & $\begin{array}{c}0.4681 \\
(0.5268)\end{array}$ & $\begin{array}{c}0.3372 \\
(0.5630)\end{array}$ & $\begin{array}{c}0.4193 \\
(0.5231)\end{array}$ & $\begin{array}{c}-5.9535 \\
(0.6896)\end{array}$ \\
\hline $\operatorname{Ln}(\mathrm{OPN})$ & $\begin{array}{l}0.1097 * \\
(0.0375) \\
\end{array}$ & $\begin{array}{c}0.1119 \\
(0.1539) \\
\end{array}$ & $\begin{array}{c}-0.1309^{*} \\
(0.0450) \\
\end{array}$ & $\begin{array}{l}0.1161 * \\
(0.0317) \\
\end{array}$ & $\begin{array}{l}0.1108 * \\
(0.0384) \\
\end{array}$ & $\begin{array}{c}0.1540 * * \\
(0.0015) \\
\end{array}$ & $\begin{array}{c}0.0349 \\
(0.9547) \\
\end{array}$ \\
\hline $\operatorname{Ln}(F D)$ & $\begin{array}{c}0.0245 \\
(0.2614) \\
\end{array}$ & $\begin{array}{c}0.0229 \\
(0.6261)\end{array}$ & $\begin{array}{c}0.0031 \\
(0.8822) \\
\end{array}$ & $\begin{array}{c}-0.0668 \\
(0.4040) \\
\end{array}$ & $\begin{array}{c}0.0156 \\
(0.4578) \\
\end{array}$ & $\begin{array}{c}0.0174 \\
(0.3480) \\
\end{array}$ & $\begin{array}{c}0.0765 \\
(0.8790) \\
\end{array}$ \\
\hline $\begin{array}{l}\text { Ln(FDI)* } \\
\text { Ln(INFR) }\end{array}$ & & $\begin{array}{l}0.0912+ \\
(0.0698)\end{array}$ & & & & & \\
\hline $\begin{array}{l}\operatorname{Ln}(\text { FDI })^{*} \\
\operatorname{Ln}(\mathrm{OPN})\end{array}$ & & & $\begin{array}{c}0.0426 * * * \\
(0.0001) \\
\end{array}$ & & & & \\
\hline $\begin{array}{l}\operatorname{Ln}(F D I)^{*} \\
\operatorname{Ln}(F D)\end{array}$ & & & & $\begin{array}{c}0.0128 \\
(0.2130) \\
\end{array}$ & & & \\
\hline $\begin{array}{l}\operatorname{Ln}(\mathrm{FDI})^{*} \\
\operatorname{Ln}(\mathrm{HC})\end{array}$ & & & & & $\begin{array}{l}0.0032+ \\
(0.0902)\end{array}$ & & \\
\hline $\begin{array}{l}\operatorname{Ln}(\mathrm{FDI})^{*} \\
\operatorname{Ln}(\mathrm{ACP})\end{array}$ & & & & & & $\begin{array}{l}0.6201 * \\
(0.0271)\end{array}$ & \\
\hline $\begin{array}{l}\text { Ln(FDI)* } \\
\text { Ln(INST) }\end{array}$ & & & & & & & $\begin{array}{c}0.0135 \\
(0.6341)\end{array}$ \\
\hline Constant & Yes & Yes & Yes & Yes & Yes & Yes & Yes \\
\hline $\begin{array}{l}\text { Year } \\
\text { dummy }\end{array}$ & Yes & Yes & Yes & Yes & Yes & Yes & Yes \\
\hline $\mathrm{N}$ & 440 & 440 & 440 & 440 & 440 & 440 & 440 \\
\hline R_square & 0.7125 & 0.7615 & 0.7460 & 0.7282 & 0.7193 & 0.7260 & 0.5316 \\
\hline Chi_square & 424.5612 & 368.4655 & 514.5734 & 433.4751 & 387.3147 & 525.2606 & 108.4888 \\
\hline Cluster & 63 & 63 & 63 & 63 & 63 & 63 & 63 \\
\hline
\end{tabular}

$+, *, * *, * * *$ statistically significant at $10 \%, 5 \%, 1 \%$ and $0.1 \%$

Standard errors are autocorrelation and heteroscedasticity corrected.

Source: own elaboration.

It might be more interesting to look at the marginal effect of FDI on provincial GDP, conditional on specific values of absorptive capacity. Therefore, our study examines it by considering three values of each dimension of absorptive capacity: minimal value, medium 
value, and maximal value. Table 3 shows the marginal effect of FDI on provincial GDP, which depends on three levels of openness, infrastructure, the absorptive capacity of domestic firms, and human capital. The first column indicates that if a province has a high level of openness, the effect of FDI on provincial growth is 0.2044 . If the level of openness is medium, the province still enjoys the benefits of FDI, but the magnitude decreases to 0.0661 . However, if the province inactively takes part in trading activities, FDI may hamper its economy. In that case, an $1 \%$ increase in FDI stock can decrease $0.1411 \%$ in GDP of the province. Importantly, based on the magnitudes, we can see that the negative impact $(-0.1411)$ is higher than the positive impact (0.0661). This situation implies a divergence among provinces witha low level of openness and provinces with the medium level of openness. The pattern of the role of domestic firms' absorptive capacity in column 3 is similar. Provinces with medium and good domestic firms can enjoy FDI spillovers, with coefficients of 0.0423 and 0.1677 , respectively. For the provinces with the low level of domestic firms' absorptive capacity, the coefficient is negative, but it is not statistically significant. Therefore, we cannot conclude that FDI negatively impacts provinces with a low level of domestic absorptive capacity. Columns 2 and 4 approve the moderating role of infrastructure and human capital. The better development of infrastructure and the higher level of workers can lead to better effects of FDI on provincial GDP. Generally, the marginal effect analysis ends up with a conclusion that the high level of absorptive capacity - for any dimensions - can help provinces enjoy more benefits from foreign investors. Conversely, the low level of absorptive capacity (the openness dimension) can hinder a province's performance.

Based on the magnitude of coefficients, we partly see that infrastructure can bring the highest impact on the link between FDI and provincial FDI. Next is the level of openness, which nevertheless requires provinces to have from medium to high level of openness. Otherwise, the reverse impact can occur. The role of human capital and the absorptive capacity of domestic firms appear equivalent. Therefore, at first glance, policymakers should pay more attention to the current state of infrastructure, the level of openness, the capacity of workers, and the capability of domestic firms.

Table 3. Marginal effects of FDI with different values of absorptive capacity

\begin{tabular}{|l|c|c|c|c|}
\hline Value & $\begin{array}{c}\mathrm{dy} / \mathrm{dx} \\
\text { at values of } \operatorname{Ln}(\mathrm{OPN})\end{array}$ & $\begin{array}{c}\mathrm{dy} / \mathrm{dx} \\
\text { at values of } \operatorname{Ln}(\mathrm{HC})\end{array}$ & $\begin{array}{c}\mathrm{dy} / \mathrm{dx} \\
\text { at values of } \operatorname{Ln}(\mathrm{ACP})\end{array}$ & $\begin{array}{c}\mathrm{dy} / \mathrm{dx} \\
\text { at values of } \operatorname{Ln}(\text { INFR) }\end{array}$ \\
\hline Min & $-0.1662^{* *}$ & 0.0243 & -0.0519 & 0.0059 \\
\hline Mean & $0.0661^{* *}$ & $0.0578^{* *}$ & $0.0423^{* *}$ & $0.0698^{* *}$ \\
\hline Max & $0.2044^{* * *}$ & $0.1446^{* *}$ & $0.1677^{*}$ & $0.3926^{* *}$ \\
\hline
\end{tabular}

$\mathrm{dy} / \mathrm{dx}: \mathrm{y}$ is $\mathrm{Ln}(\mathrm{Y} / \mathrm{L})$ and $\mathrm{x}$ is $\operatorname{Ln}(\mathrm{FDI})$

$* * *, * *, *$ are statistically significant at $0.1 \%, 1 \%$ and $5 \%$

Source: own study.

\section{CONCLUSIONS}

The article scrutinizes the role of absorptive capacity at the provincial level in Vietnam by considering the absorptive capacity of domestic firms in provinces a component of the absorptive capacity of provinces. Although the article offers several findings, it also has some limitations that can be improved in further studies. The main limitation of the article lies in the proxy of institutions and financial development. Regarding institutions, the article uses 
the $\mathrm{PCl}$ as indices at the provincial level. However, data for each province from the small country where policy is mostly homogenous might be not the best proxy for institutions. Furthermore, although the $\mathrm{PCl}$ covers important sectors, it is unlikely to fully cover all institutions. In addition, the proxy for the financial development of provinces seems not the best one. Moreover, at the cross-country level, openness can reflect the differences in trading policy, but at the provincial level, especially in a small country like Vietnam, it may bring different results. Therefore, the study requires a better proxy. Another shortcoming of our article is that we apply a random effect model based on a strict assumption that there are no correlations between error terms and covariates. Technically, the Hausman test confirms that the use of a random model with this database is valid, although such an assumption is quite strict. Therefore, this study has room for improvement.

The importance of absorptive capacity in the link from FDI to economic development examines the case of 63 provinces of Vietnam from 2007 to 2015. The article argues that absorptive capacity includes six components which are: financial development, human capital, the level of openness, the absorptive capacity of domestic firms, institutions, and infrastructure. We connect absorptive capacity at the firm level with absorptive capacity at the provincial level by constructing the former as a component of the latter. The singlefactor measurement model of CFA is applied to test the measurement of absorptive capacity, which shows that the construct of absorptive capacity is valid and fits the employed database. We then apply G2SLS random effect IV regression to receive the following findings. Firstly, FDI has a positive and significant effect on the GDP of 63 provinces of Vietnam. Secondly, among six dimensions, only four affect provincial development positively: infrastructure, human capital, the level of openness, and the absorptive capacity of domestic firms. Moreover, the four dimensions also play a moderating role in linking positive externalities from FDI with provinces. Finally, based on the magnitude of coefficients and marginal effect analysis, we suggest that the most important dimensions of absorptive capacity are infrastructure, the level of openness, human capital, and the absorptive capacity of domestic firms. The result of this article contributes to the policymaking process at the national and provincial level. At the provincial level, policymakers can look at the importance of absorptive capacity at each component, and they might prioritize certain factors over others. At the national level, our article offers a foundation for policymakers to decide about the attraction and distribution of FDI projects.

\section{REFERENCES}

Acemoglu, D., Johnson, S., \& Robinson, J. (2005). Institutions as a Fundamental Cause of Long-Run Growth. Handbook of Economic Growth, 1A, 386-472.

Alfaro, L., Chanda, A., \& Kalemli-ozcan, S. (2004). FDI and economic growth : the role of local financial markets. Journal of International Economics, 64, 89-112. https://doi.org/10.1016/S00221996(03)00081-3

Bell, M., \& Pavitt, K. (1992). Accumulating Technological Capability in Developing Countries. World Bank Economic Review, (S), 257-281.

Borensztein, E., De Gregorio, J., \& Lee, J.-W. (1998). How does foreign direct investment affect economic growth?. Journal of International Economics, 45, 115-135. https://doi.org/10.1080/10978526.2010.486715 
Carkovic, M., \& Levine, R. (2005). Does Foreign Direct Investment Accelerate Economic Growth?. In T. Moran, E. Graham, \& M. Blomstrom (Eds.), Does Foreign Direct Investment Promote Development? (pp. 195-220). Washington DC: Peterson Institute for International Economics.

Cohen, W.M., \& Levinthal, D.A. (1989). Innovation and Learning: The Two Faces of R \& D. The Economic Journal, 99(397), 569-596. Retrieved from http://www.jstor.org/stable/2233763 on January 20, 2019.

Cohen, W. M., \& Levinthal, D.A. (1994). Fortune Favors the Prepared Firm. Management Science, 40(2), 227-251.

Cohen, W.M., \& Levinthal, D.A. (1990). Absorptive Capacity: A New Perspective on Learning and Innovation. Administrative Science Quarterly, 35(1), 128-152. Retrieved from http://www.jstor.org/stable/2393553 on May 21, 2019.

Durham, J.B. (2004). Absorptive capacity and the effects of foreign direct investment and equity foreign portfolio investment on economic growth. European Economic Review, 48(2), 285-306. https://doi.org/10.1016/S0014-2921(02)00264-7

Fu, X. (2008). Foreign Direct Investment, Absorptive Capacity and Regional Innovation Capabilities: Evidence from China. Oxford Development Studies, 36(1). https://doi.org/10.1080/13600810701848193

Lai, M., Peng, S., \& Bao, Q. (2006). Technology spillovers, absorptive capacity and economic growth. China Economic Review, 17(3), 300-320. https://doi.org/10.1016/j.chieco.2006.04.005

Lane, P.J., Koka, B.R., \& Pathak, S. (2006). The reification of absorptive capacity: A critical review and rejuvenation of the construct. Academy of Management Review, 31(4), 833-863. https://doi.org/10.5465/AMR.2006.22527456

Lane, P.J., \& Lubatkin, M. (1998). Relative absorptive capacity and interorganizational learning. Strategic Management Journal, 19(5), 461-477. https://doi.org/10.1002/(SICI)10970266(199805)19:5<461::AID-SMJ953>3.0.CO;2-L

Malesky, E., \& Taussig, M. (2009). Out of the Gray: The Impact of Provincial Institutions on Business Formalization in Vietnam. Journal of East Asian Studies, 9(2), 249-290. Retrieved from http://10.0.3.249/S1598240800003003 on June 21, 2019.

Nguyen, H.T., Duysters, G., Patterson, J.H., \& Sander, H. (2009). Foreign Direct Investment Absorptive Capacity Theory.

Schillaci, C.E., Romano, M., \& Nicotra, M. (2013). Territory's Absorptive Capacity. Entrepreneurship Research Journal, 3(1), 109-126. Retrieved from http://10.0.5.235/erj-2012-0001 on May 21, 2019.

Szulanski, G. (1996). Exploring internal stickiness: Impediments to the transfer of best practice within the firm. Strategic Management Journal, 17(S2), 27-43. https://doi.org/10.1002/smj.4250171105

Thang, T.T., Pham, T.S.H., \& Barnes, B.R. (2016). Spatial Spillover Effects from Foreign Direct Investment in Vietnam. Journal of Development Studies, 52(10), 1431-1445. Retrieved from http://www.tandfonline.com/loi/fjds20 on May 21, 2019.

Zahra, S.A., \& George, G. (2002). Absorptive Capacity: A Review, Reconceptualization, And Extension. Academy of Management Review, 27(2), 185-203.

Resolution 02/NQ-CP dated 01/01/2019 on Về Tiếp Tục Thực Hiện Những Nhiệm Vụ, Giải Pháp Chủ Yếu Cải Thiện Môi Trường Kinh Doanh, Nâng Cao Năng Lực Cạnh Tranh Quốc Gia Năm 2019 Và Định Hướng Đến Năm 2021 [Solutions to improve business environment and national competitiveness in 2019, toward 2021]. Retrieved from https://thuvienphapluat.vn/ on May 21, 2019. 
Appendix A: Model Specification tests

\begin{tabular}{|c|c|c|c|}
\hline Hypotheses & Test & Test value & Decision \\
\hline $\begin{array}{l}\mathrm{H}_{0}: \text { Random effect model } \\
\mathrm{H}_{1}: \text { Fixed effect model }\end{array}$ & Hausman test & Chi-square $=0.06$ & Not reject $\mathrm{H}_{0}$ \\
\hline $\begin{array}{l}\mathrm{H}_{0} \text { : Instruments are valid } \\
\mathrm{H}_{1} \text { : Instruments are invalid }\end{array}$ & Hansen test & Chi-square $=48.17$ & Not reject $\mathrm{H}_{0}$ \\
\hline $\begin{array}{l}\mathrm{H}_{0} \text { : coefficients of endogenous regressors } \\
\text { are jointly } 0\end{array}$ & $\begin{array}{l}\text { Anderson-Rubin } \\
\text { Wald test }\end{array}$ & $F(8,62)=30.92$ & Reject $\mathrm{H}_{0}$ \\
\hline $\begin{array}{l}\mathrm{H}_{1} \text { : coefficients of endogenous regressors } \\
\text { not jointly } 0\end{array}$ & $\begin{array}{l}\text { Stock-Wright LM } \\
\text { S statistic }\end{array}$ & Chi-square $=27.96$ & Reject $\mathrm{H}_{0}$ \\
\hline $\begin{array}{l}\mathrm{H}_{0}: \text { Weak identification Ln(FDI) } \\
\mathrm{H}_{1}: \text { Not weak }\end{array}$ & \multirow{8}{*}{$\begin{array}{l}\text { Sanderson- } \\
\text { Windmeijer }\end{array}$} & $F(1,62)=579.89$ & Reject $\mathrm{H}_{0}$ \\
\hline $\begin{array}{l}\mathrm{H}_{0}: \text { Weak identification } \ln (\text { INFR) } \\
\mathrm{H}_{1} \text { : Not weak }\end{array}$ & & $F(1,62)=663.30$ & Reject $\mathrm{H}_{0}$ \\
\hline $\begin{array}{l}\mathrm{H}_{0}: \text { Weak identification } \operatorname{Ln}(\mathrm{HC}) \\
\mathrm{H}_{1}: \text { Not weak }\end{array}$ & & $F(1,62)=331.54$ & Reject $\mathrm{H}_{0}$ \\
\hline $\begin{array}{l}\mathrm{H}_{0}: \text { Weak identification } \operatorname{Ln}(A C P) \\
\mathrm{H}_{1}: \text { Not weak }\end{array}$ & & $F(1,62)=210.57$ & Reject $\mathrm{H}_{0}$ \\
\hline $\begin{array}{l}\mathrm{H}_{0}: \text { Weak identification } \operatorname{Ln}(\text { INST) } \\
\mathrm{H}_{1} \text { : Not weak }\end{array}$ & & $F(1,62)=67.87$ & Reject $\mathrm{H}_{0}$ \\
\hline $\begin{array}{l}\mathrm{H}_{0}: \text { Weak identification } \mathrm{Ln}(\mathrm{K} / \mathrm{L}) \\
\mathrm{H}_{1}: \text { Not weak }\end{array}$ & & $F(1,62)=657.27$ & Reject $\mathrm{H}_{0}$ \\
\hline $\begin{array}{l}\mathrm{H}_{0}: \text { Weak identification } \operatorname{Ln}(\mathrm{OPN}) \\
\mathrm{H}_{1} \text { : Not weak }\end{array}$ & & $F(1,62)=266.15$ & Reject $\mathrm{H}_{0}$ \\
\hline $\begin{array}{l}\mathrm{H}_{0}: \text { Weak identification Ln(FD) } \\
\mathrm{H}_{1}: \text { Not weak }\end{array}$ & & $F(1,62)=106.56$ & Reject $\mathrm{H}_{0}$ \\
\hline $\begin{array}{l}\mathrm{H}_{0}: \text { No autocorrelation first level } \\
\mathrm{H}_{1} \text { : Autocorrelation first level }\end{array}$ & \multirow{2}{*}{ Arellano -Bond } & $Z=-2.15$ & Reject $\mathrm{H}_{0}$ \\
\hline $\begin{array}{l}\mathrm{H}_{0} \text { : No autocorrelation second level } \\
\mathrm{H}_{1} \text { : Autocorrelation second level }\end{array}$ & & $Z=-0.94$ & Not reject $\mathrm{H}_{0}$ \\
\hline
\end{tabular}


Appendix B: The distribution of variables
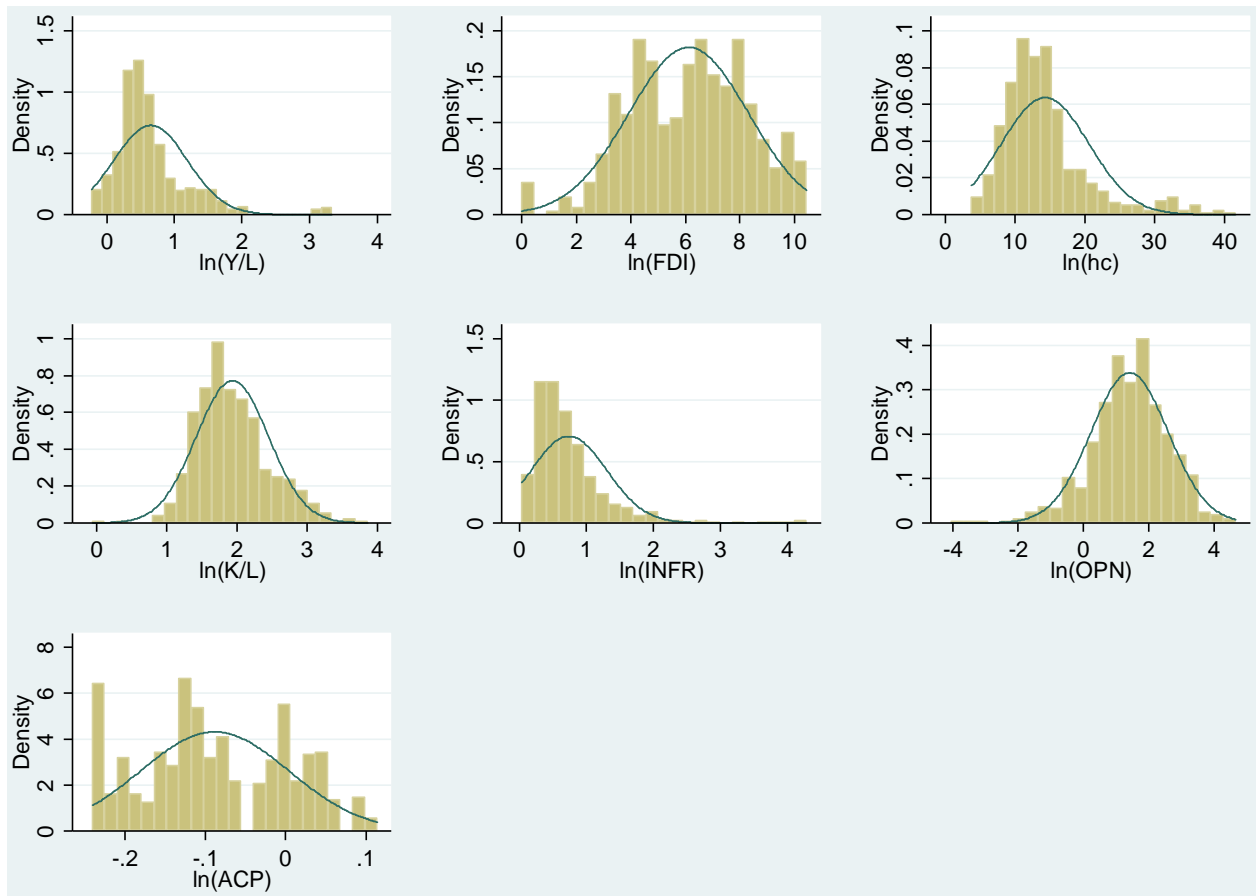

Source: own elaboration. 


\section{Authors}

The contribution of Duong Hoang Vu is $55 \%$ and the contribution of Tri Thanh Ho is $45 \%$.

\section{Duong Hoang Vu}

PhD student at the Tomas Bata University in Zlin, Czech Republic; Researcher at the Vietnam Institute of Economics, Vietnam Academy of Social Sciences, Vietnam. His research interests include foreign direct investment, poverty, and political participation.

Correspondence to: PhD candidate, Tomas Bata University in Zlin, Czech Republic, nám. T. G. Masaryka 5555, 76001 Zlín Czech Republic, e-mail: hoangduongvu87@gmail.com

ORCID (1) http://orcid.org/0000-0002-2651-2923

\section{Tri Thanh Ho}

PhD student at the Tomas Bata University in Zlin, Czech Republic; Researcher at the Industrial University of Ho Chi Minh city, Vietnam. His research interests include foreign direct investment and financial systems.

Correspondence to: Ho Thanh Tri, PhD candidate, Tomas Bata University in Zlin, Czech Republic, nám. T.G. Masaryka 5555, 76001 Zlín Czech Republic, e-mail: hothanhtri@gmail.com

ORCID (1) http://orcid.org/0000-0002-2651-2923

\section{Acknowledgements and Financial Disclosure}

This work is supported by the project No. IGA/FaME/2018/019 FDI absorptive capacity and the factor determining FDI flows in developing countries of Asia and Africa.

\section{Copyright and License}

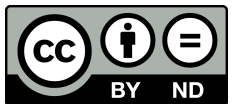

This article is published under the terms of the Creative Commons

Attribution - NoDerivs (CC BY-ND 4.0) License

http://creativecommons.org/licenses/by-nd/4.0/

\section{Published by the Centre for Strategic and International Entrepreneurship - Krakow, Poland}

